\title{
Single tertiary care centre experience of ovarian granulosa cell tumour in Chennai, India: a retrospective analysis
}

\author{
Deenadayalan T., S. Lakshmi Narasimhan*, K. Kalaichelvi, \\ B. Ramkumar, Kanchana Madurai Padmanabhan
}

Department of Medical Oncology, Institute of Obstetrics and Gynecology, Madras Medical College, Chennai, Tamil Nadu, India

Received: 12 September 2017

Accepted: 05 October 2017

\section{*Correspondence:}

Dr. S. Lakshmi Narasimhan,

E-mail: drnarasimhan@rediffmail.com

Copyright: () the author(s), publisher and licensee Medip Academy. This is an open-access article distributed under the terms of the Creative Commons Attribution Non-Commercial License, which permits unrestricted non-commercial use, distribution, and reproduction in any medium, provided the original work is properly cited.

\section{ABSTRACT}

Background: Granulosa cell tumours of ovary are rare sex-cord stromal tumours characterized by long natural history and favourable prognosis. The present study was done to evaluate the clinical presentation, treatment, outcome, and prognostic factors for patients diagnosed as granulosa cell tumours.

Methods: A Retrospective study of Granulosa cell tumour of the ovary was done for a period of five years from January 2011 to December 2015 at a tertiary care centre, Institute of Obstetrics and Gynaecology, Madras Medical College, Chennai. The clinical data and the treatment details were retrieved from the records of medical oncology department and the data were analysed.

Results: Twenty five patients were diagnosed as granulose cell tumours of ovary during the study period. The median patient age was 48 years. The most common clinical presentation at diagnosis was vaginal bleeding (76\%) followed by abdominal pain (40\%). Mean tumor size was $9.6 \mathrm{~cm}$. The majority of patients were diagnosed in FIGO stage Ia $(84 \%, \mathrm{n}=21)$. Thirteen patients $(52 \%)$ underwent complete staging laparotomy. Twenty three patients $(92 \%)$ had Adult Granulosa cell tumour. Two patients $(8 \%)$ had juvenile Granulosa cell tumour. After surgery, all patients were put on observation except two patients who received adjuvant chemotherapy (EP: Etoposide, Cisplatin). The median followup period was 48 months. Five patients (20\%) had recurrence; The average time to relapse was 29.6 months. Patients who had tumour size more than $9.7 \mathrm{~cm}$ had more recurrence events (Hazard Ratio(HR):1.058), but their association is not significant ( $\mathrm{P}$ value-0.839). The association between menopausal status, torsion of tumour mass, tumour stage with recurrence rate were not significant. The estimated mean overall survival was 84.8 months. Following univariate Cox regression modeling, survival appeared to be independent of age range, post operative residual tumour and the FIGO stage.

Conclusions: Granulosa cell tumours of ovary are rare, often diagnosed in early stage. Patients who had tumour size of more than $9.7 \mathrm{~cm}$ had more recurrence events. A prolonged post therapeutic follow-up is necessary to pick up the late relapses.

Keywords: Chemotherapy, Granulosa cell tumour, Juvenile granulosa cell tumour, Metastasis, Recurrence

\section{INTRODUCTION}

Ovarian sex cord-stromal tumors are a heterogeneous group of benign or malignant tumors. They develop from the dividing cell population which originally produce cells that support and surround the oocytes, including the cells that produce ovarian hormones. Ovarian sex cordstromal tumors are rare, comprising only $2-3 \%$ of all primary ovarian cancers. Sex cord-stromal tumors include fibroma-thecomas, granulosa cell tumors (which differentiate toward female characteristics), and Sertoli- 
Leydig cell tumors (which differentiate toward male characteristics).

Granulosa cell tumors have malignant potential (i.e., the ability to metastasize). They are the most common type of potentially malignant ovarian sex cord-stromal tumor. ${ }^{1}$ They were first described in 1855 by Rokitansky. He described them according to their appearance near the granulosa cells of ovarian follicles. There are two subtypes, adult and juvenile.

The adult subtype, which occurs most commonly in middle-aged and older women (median age, 50 to 54 years), comprises 95 percent of these neoplasms. The juvenile type comprises 5 percent of all granulosa cell tumours. They typically develop before puberty, and thus, are more common among children and young women. This subtype tends to have a higher proliferative rate than the adult type and a lower risk for late recurrences. ${ }^{2}$

In contrast with epithelial ovarian cancer, most patients with malignant sex cord-stromal tumors are diagnosed with early-stage disease; the tumors are generally considered to be low-grade malignancies. ${ }^{3}$ Most Granulosa Cell tumours present with symptoms related to estrogen secretion, such as abnormal vaginal bleeding or precocious puberty.

Complete surgical resection is the mainstay of treatment, particularly in early stage patients. Adjuvant treatment with platinum-based chemotherapy is indicated for advanced stages. Granulosa Cell tumours usually have a relatively favorable prognosis. However, late relapse often occurs due to an indolent disease course, and the prognosis of advanced disease is poor, with a 5-year survival rate of $0 \%$ to $20 \%$, comparable to that for epithelial ovarian cancer. ${ }^{4}$

Prognostic factors for Granulosa Cell tumours have been reported previously and include age, tumor size, tumor rupture, tumor stage, bilaterality, postoperative residual tumour status and high mitotic index (5-15). However, prognostic factors for Granulosa Cell tumour and it's recurrent nature remain unclear, due to rarity and indolent course of the disease. Furthermore, there are only few data that would indicate the development of optimal therapy for recurrent Granulosa cell tumours. Hence present study was conducted to find out the clinicopathological features, prognostic factors for recurrence and treatment options.

\section{METHODS}

All cases of granulose cell tumour who were pathologically proven and treated between January 2011 to December 2015 at Department of Medical Oncology, Institute of Obstetrics and Gynecology, Madras Medical College in Chennai were included in this study. Twenty five cases were eligible for analysis.
We retrospectively reviewed all available medical records to obtain information on the patient characteristics, clinical presentation, International Federation of Gynecology and Obstetrics (FIGO) stage, surgical procedures, tumour size, postoperative residual tumour status, adjuvant treatments, recurrence patterns, management of recurrence, and the follow-up.The patients were followed up until June 2017.

Tumour size was determined by preoperative ultrasonogram or computed tomography. All patients underwent surgical management. Complete staging laparotomy includes total abdominal hysterectomy + bilateral salphingo-oophorectomy with optimal resection (R0), omentectomy, \pm lymphadenectomy and multiple biopsies. All other operations constituted partial surgical staging. Fertility-sparing operation (FSO) was defined as the preservation of the uterus and at least one adnexa. Patients with advanced stage (stage II-IV) and those with recurrence received chemotherapy. Other patients were put on active surveillance.

\section{Statistical analysis}

The collected data were analysed with IBM.SPSS statistics software 23.0 Version. To describe about the data descriptive statistics, frequency analysis, percentage analysis was used for categorical variables and the mean and standard deviation were used for continuous variables. To find the significant difference between the bivariate samples in Paired groups the Paired sample ttest was used and for Independent groups the Unpaired sample t-test was used. Univariate analyses were performed using the Cox proportional hazards regression. To find the significance in categorical data, the Fisher's Exact was used. In all the above statistical tools the probability value 0.05 was considered as significant level.

\section{RESULTS}

\section{Clinical features}

Totally 25 cases were registered during the period from January 2011 to December 2015. It accounted for 4\% of all ovarian cancers of that time period. The median age of the patients was 48 years. For $84 \%$ of the patients, the tumor occurred between the fifth and seventh decades. Among the patients, $80 \%$ were multipara $(n=20) ; 16 \%$ nullipara and $56 \%$ of the patients $(n=14)$ were post menopausal.

A total of $40 \%$ of the patients $(n=10)$ presented with abdominal pain at diagnosis and also presented with vaginal bleeding as follows: intermenstrual bleeding $(32 \%, \mathrm{n}=8)$, postmenopausal bleeding $(44 \%, \mathrm{n}=11)$. Other symptoms included palpable mass $(20 \%, \mathrm{n}=5)$ and virilization $(4 \%, \mathrm{n}=1)$. The average tumour size was 9.8 $\mathrm{cm}$ (range: 6 to $20 \mathrm{~cm}$ ). A summary of patient characteristics is presented below in Table 1 and 2 . 
Table 1: A summary of patient characteristics.

\begin{tabular}{|ll|}
\hline Characteristic & \\
\hline Age, median (range), years & $48(7-70)$ \\
\hline$<10$ & $1(4 \%)$ \\
\hline $10-19$ & $1(4 \%)$ \\
\hline $20-29$ & $2(8 \%)$ \\
\hline $30-39$ & 0 \\
\hline $40-49$ & $10(40 \%)$ \\
\hline $50-59$ & $7(28 \%)$ \\
\hline $60-70$ & $4(16 \%)$ \\
\hline$>70$ & 0 \\
\hline Parity, n $(\%)$ & \\
\hline Nullipara & $4(16 \%)$ \\
\hline I & $1(4 \%)$ \\
\hline II & $11(44.0 \%)$ \\
\hline III & $2(8.0 \%)$ \\
\hline IV & $4(16 \%)$ \\
\hline V & $3(12 \%)$ \\
\hline Menopausal, n (\%) & $14(56 \%)$ \\
\hline
\end{tabular}

Table 2: Patients' symptomatology at diagnosis.

\begin{tabular}{|ll|}
\hline Symptoms & N $(\%)$ \\
\hline Abdominal pain & $10(40 \%)$ \\
\hline Palpable mass & $5(20 \%)$ \\
\hline Abdominal distension & $1(4 \%)$ \\
\hline Precocious puberty & $1(4 \%)$ \\
\hline Virilization & $1(4 \%)$ \\
\hline Mastalgia & $1(4 \%)$ \\
\hline Menorrhagia & $8(32 \%)$ \\
\hline Post menopausal bleeding & $11(44 \%)$ \\
\hline Secondary amenorrhea & 0 \\
\hline Lower urinary tract symptoms & 0 \\
\hline Constipation & 0 \\
\hline
\end{tabular}

\section{Treatment}

Thirteen patients (52\%) underwent complete staging laparotomy. After surgery all these patients were put on observation without adjuvant chemotherapy. Only one patient received adjuvant treatment (EP:Etoposide, Cisplatin), as she had advanced disease with omental involvement (Stage IIIa). She completed 6 cycles of EP and on regular follow up since 2012 and disease free. In this patient population, only one patient (4\%) had recurrence. That patient developed pelvic metastasis 75 months after surgery, As the mass was inoperable, she was started on palliative chemotherapy (EP regimen). Till June 2017 she received four cycles of EP and her disease is stable.

Eight patients (32\%) underwent incomplete staging laparotomy. Among them one patient received adjuvant chemotherapy who had disease in para aortic node after surgery. She received one cycle of EP and then she defaulted. All other patients were put on observation. Among those on observation two patients developed recurrence.
One patient was diagnosed to have metastasis to omentum and para aortic node 24 months after primary surgery. She had undergone omentectomy, pelvic and para aortic lymhadenectomy, followed by 4 cycles of chemotherapy with EP regimen in 2015. She is on regular follow up till date without evidence of disease. Another patient developed multiple cystic liver metastasis 24 months after primary surgery. She was advised chemotherapy, but she defaulted.

Four patients $(16 \%)$ had fertility preserving operation i.e. unilateral oophorectomy.

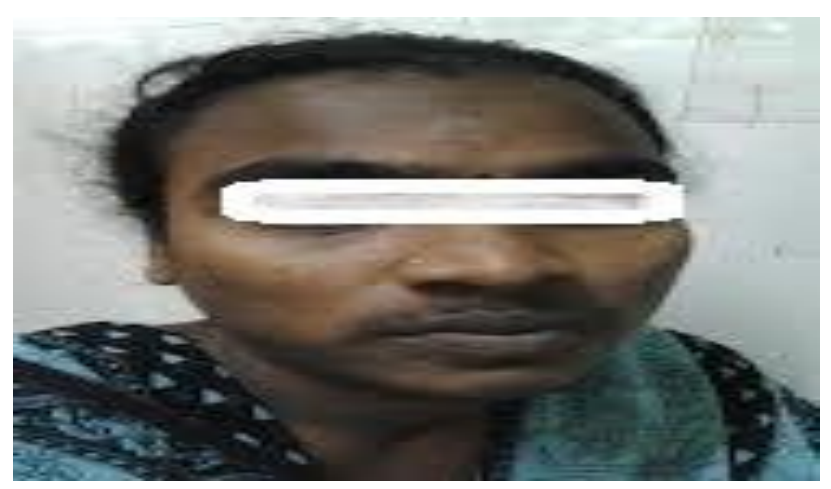

Figure 1: A case of juvenile granulosa cell tumour with virilisation features.

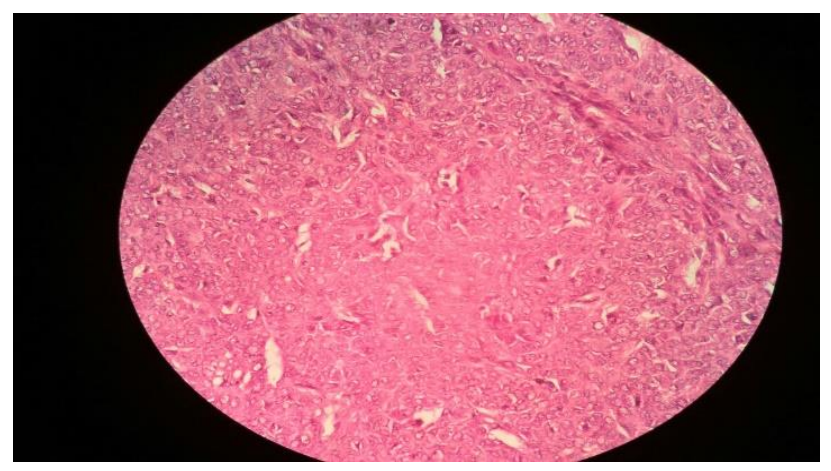

Figure 2: Adult Granulosa Cell Tumour (HandE) x 40: showing diffuse pattern with scant neoplasm, pale nucleus with prominent nuclear grooves.

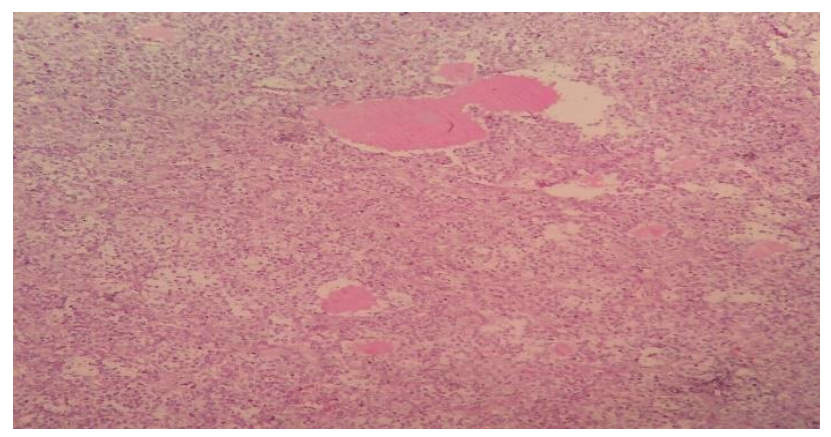

Figure 3: Juvenile Granulosa Cell Tumour (HandE) $x$ 40: shows follicular pattern with lumen containing eosinophilic secretion and characterstic round hyperchromatic nucleus without nuclear grooves. 
All were put on observation. Among them two patients developed recurrence. One patient (with juvenile granulose cell tumour) developed metastasis in pelvis and omentum, 13 months after surgery. She received three lines of palliative chemotherapy (EP regimen, Docetaxel and Carboplatin and oral cyclophosphamide) before death. Another patient (with adult granulose cell tumour) developed liver metastasis 12 months after surgery. She defaulted for chemotherapy inspite of our advice.

Table 3: Patients' treatment details and intra operative findings.

\begin{tabular}{|c|c|}
\hline $\begin{array}{l}\text { Surgical approach, n (\%) } \\
\text { Laparotomy Laparoscopy }\end{array}$ & $\begin{array}{l}25(100 \%) \\
0\end{array}$ \\
\hline \multicolumn{2}{|l|}{ FIGO stage, $n(\%)$} \\
\hline Ia & $21(84 \%)$ \\
\hline $\mathrm{Ib}$ & $2(8.0 \%)$ \\
\hline Ic & $1(4.0 \%)$ \\
\hline IIa & 0 \\
\hline IIb & 0 \\
\hline IIc & 0 \\
\hline IIIa & $1(4.0 \%)$ \\
\hline IIIb & 0 \\
\hline IIIc & 0 \\
\hline \multicolumn{2}{|l|}{ Surgical staging, n (\%) } \\
\hline Complete staging & $13(52 \%)$ \\
\hline Incomplete staging & $12(48 \%)$ \\
\hline \multicolumn{2}{|l|}{ PLND, n (\%) } \\
\hline No & $25(100 \%)$ \\
\hline Yes & 0 \\
\hline \multicolumn{2}{|l|}{ Fertility-sparing surgery, n (\%) } \\
\hline Yes & $4(16 \%)$ \\
\hline No & $21(84 \%)$ \\
\hline \multicolumn{2}{|c|}{ Postoperative residual tumor, n (\%) } \\
\hline Yes & $2(8 \%)$ \\
\hline No & $23(92 \%)$ \\
\hline \multicolumn{2}{|c|}{ Intraoperative rupture of tumor, $n(\%)$} \\
\hline Yes & $1(4 \%)$ \\
\hline No & $24(96 \%)$ \\
\hline \multicolumn{2}{|l|}{ Peritoneal fluid cytology, n (\%) } \\
\hline Positive & 0 \\
\hline Negative & $15(60 \%)$ \\
\hline Not measured & $10(40 \%)$ \\
\hline Bilaterality, $\mathrm{n}(\%)$ & $3(12 \%)$ \\
\hline Tumor size, median (range), $\mathrm{cm}$ & $9.6(6.0-20.0)$ \\
\hline \multicolumn{2}{|l|}{ Endometrial status, n (\%) } \\
\hline Proliferative phase & $12(48 \%)$ \\
\hline Simple Endometrial hyperplasia & $4(16 \%)$ \\
\hline $\begin{array}{l}\text { Complex Endometrial hyperplasia } \\
\text { with atypia }\end{array}$ & $1(4 \%)$ \\
\hline $\begin{array}{l}\text { Complex Endometrial hyperplasia } \\
\text { without atypia }\end{array}$ & $1(4 \%)$ \\
\hline Post hysterectomy & $2(8 \%)$ \\
\hline Endometrial cancer & 0 \\
\hline Polyp & 0 \\
\hline Not measured & $5(20 \%)$ \\
\hline
\end{tabular}

Two patients had juvenile granulosa cell tumor. One patient was diagnosed at 7 years of age who presented with precocious puberty and mastalgia in 2012. She underwent FSO and then was put on observation. She is on regular follow up till date and disease free. Another patient was diagnosed at 19 years of age. She presented with torsion of ovarian mass and virilisation features (Figure 1). She underwent FSO and then was put on observation. She developed metastasis in pelvis and omentum, 13 months after surgery. She received three lines of palliative chemotherapy (EP regimen, Docetaxel and Carboplatin and oral cyclophosphamide) before death (OS-21months).

Eighteen patients $(72 \%)$ had endometrial biopsies. The results were as follows: twelve patients had proliferative endometrium.

Four patients were found to have endometrial hyperplasia including a complex hyperplasia with atypia. A summary of management and outcomes of patients is given in Figure 4. The treatment details and intra operative findings are mentioned in Table 3.

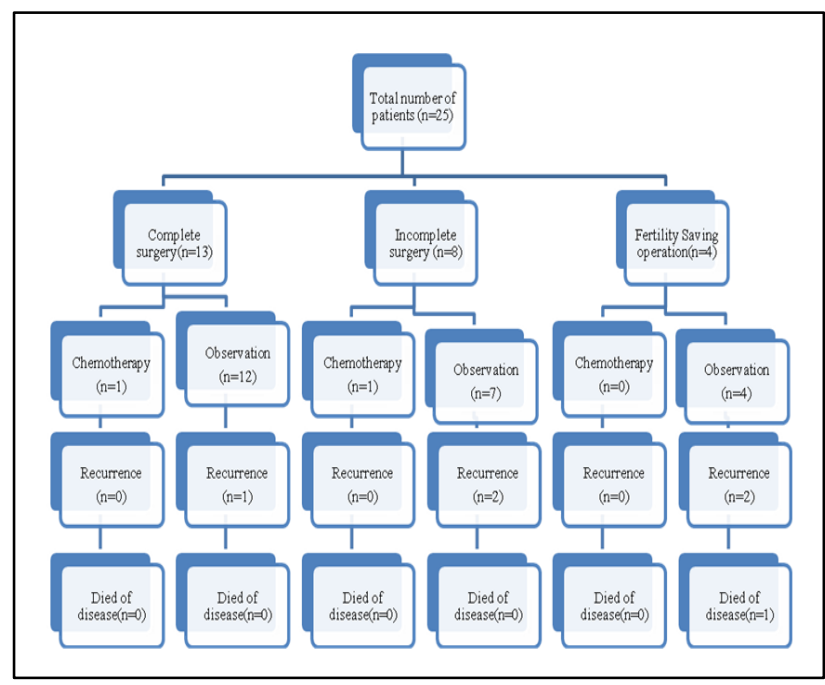

Figure 4: Management and outcomes of patients.

\section{Staging}

The staging breakdown was as follows: stage Ia $(84 \%, \mathrm{n}$ $=21)$, stage $\mathrm{Ib}(8 \%, \mathrm{n}=2)$ stage Ic $(4 \%, \mathrm{n}=1)$ and stage IIIa $(4 \%, \mathrm{n}=1)$.

\section{Recurrence and survival}

On median follow-up of 48 months, five patients (20\%) had recurrence, and one of those patients died of the disease. Patient characteristics for those patients with relapse disease are shown below in Table 4 . The average time to relapse was 29.6 months, (95\% Confidence interval :12.3- 46.8 months) (Figure 5). Receiver Operative Curve (ROC) is used to arrive cut-off value of tumor size to assess the chance of recurrence, which was 
Table 4: Patient characteristics for those with relapse disease.

\begin{tabular}{|llllllll|} 
Case & Age (years) & Stage & $\begin{array}{l}\text { Size of } \\
\text { tumor }(\mathbf{c m})\end{array}$ & $\begin{array}{l}\text { Primary } \\
\text { treatment }\end{array}$ & $\begin{array}{l}\text { Time to relapse } \\
\text { (months) }\end{array}$ & $\begin{array}{l}\text { Site of relapse } \\
\text { Treatment for } \\
\text { relapsae }\end{array}$ \\
\hline 1 & 21 & Ia & 10 & FSO & 12 & Liver & Oefaulted \\
\hline 2 & 52 & Ia & NA & Incomp Surg & 24 & Liver & Surgery+Chemo \\
\hline 3 & 55 & Ia & 6 & Incomp Surg & 24 & Omentum+pelvis & Chemo \\
\hline 4 & 19 & Ia & 10 & FSO & 13 & Pelvis & Chemo \\
\hline 5 & 28 & Ia & 7 & Comp Surg & 75 &
\end{tabular}

FSO-Fertility Saving Operation; NA-not available; Incomp Surg- Incomplete Surgery; Comp Surg- Complete Surgery; ChemoChemotherapy

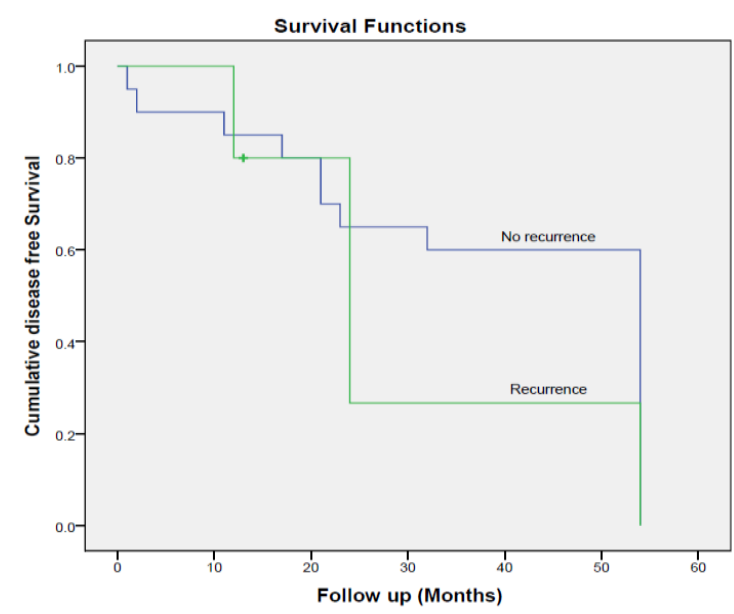

Figure 5: Kaplan-Meier plot: cumulative disease free survival.

But the association of tumour size cut off $(>9.7 \mathrm{~cm})$ with recurrence rate is not significant according to Log Rank (Mantel-Cox) test (P value-0.839) (Figure 6).

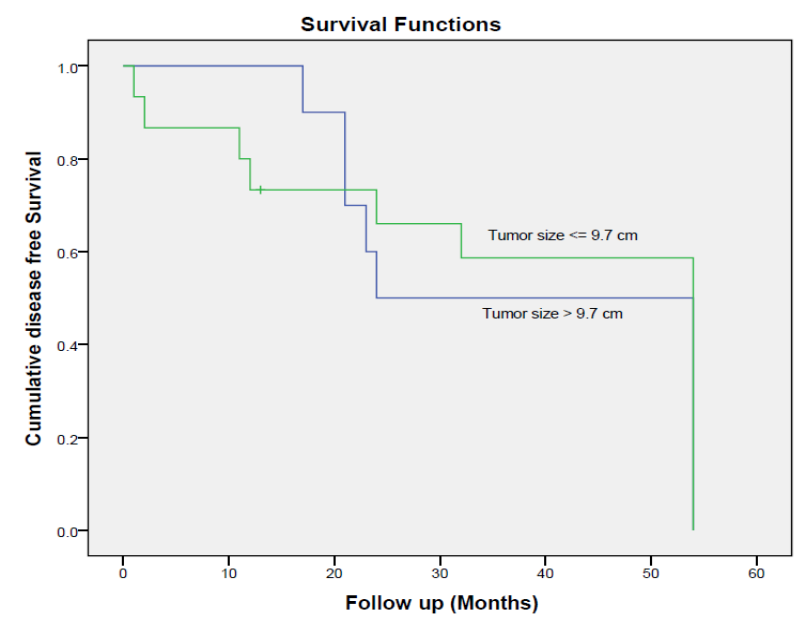

Figure 6: Kaplan-Meier plot: cumulative disease free survival by tumor size.
The associations between menopausal state ( $\mathrm{P}$ value$1.00)$, torsion of tumor mass ( $\mathrm{P}$ value-0.54), tumor stage ( $\mathrm{P}$ value- 0.65$)$ with recurrence rate are not significant. The estimated mean overall survival is 84.8 months $(95 \%$ Confidence interval 74.3-95.4 months) (Figure 7).

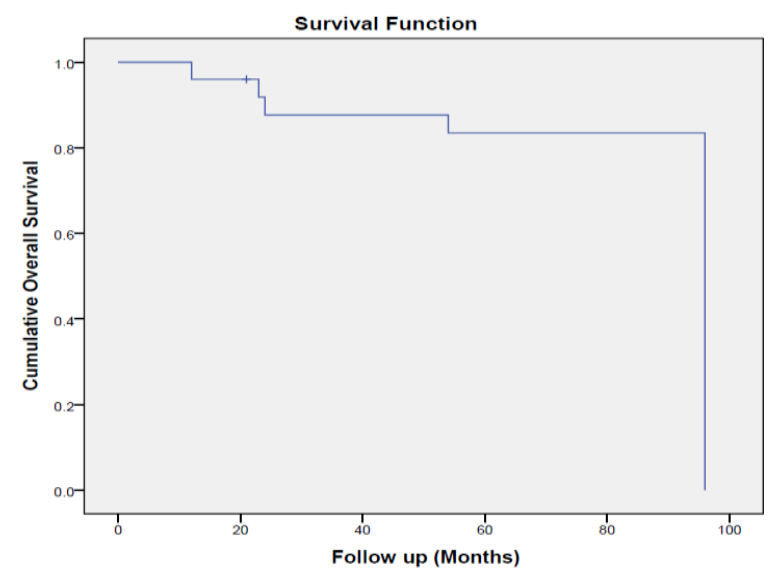

Figure 7: Kaplan-Meier plot: cumulative overall survival.

According to T-Test, there was no significant mean difference between pre menopausal and post menopausal groups regarding DFS ( $\mathrm{P}$ value-0.57) and OS ( $\mathrm{P}$ value0.27). Following univariate Cox regression modeling, survival appears to be independent of age range ( $\mathrm{P}$ value0.66 ; HR-0.026), post operative residual tumor ( $\mathrm{P}$ value0.83 ; HR-0.042) and the FIGO stage (P value-0.84; HR$0.321)$.

\section{DISCUSSION}

Granulosa cell tumors are malignant sex cord stromal tumours. ${ }^{1}$ It has two histological types: a juvenile type (5\%) and an adult type (95\%). Adult type commonly occurs in postmenopausal women in $5^{\text {th }}$ decade and has good prognosis. Juvenile type is characterized by occurrence at an early age, with pronounced signs of malignancy and an increased risk of recurrence. ${ }^{2}$ In this 
study, we also documented similar age distribution and and the worse prognosis of juvenile subtype.

In a retrospective study of 118 patients with granulosa cell tumors, $55 \%$ had hyperoestrogenic findings including abnormal uterine bleeding, post menopausal bleeding, menstrual abnormalities and hyperplastic endometrium. ${ }^{3}$ Hyperoestrogenism may produce sexual precocity, mastalgia and galactorrhea in children. Endometrial hyperplasia is present in 25 to 50 percentage of women with granulosa cell tumor and endometrial carcinoma in 5-10 percentage. $^{4}$

Radiologically granulosa cell tumors present as a solid tumour with cystic component and median size of $12 \mathrm{~cm}$ (range 1 to $30 \mathrm{~cm}$ ). ${ }^{5}$ The diagnosis of granulosa cell tumor is made by histopathological examination at the time of surgical excision. The adult form has 5 subtypes, most common is micro follicular with call-exner bodies. The juvenile form is associated with macro follicular lobulated architecture with frequent mitosis and infrequent call-exner bodies.

The common immuno-histochemical markers expressed by these cells are alpha inhibin, CD99 and vimentin. ${ }^{6}$ The serum tumor markers are inhibin, estradiol and anti mullerian hormone. ${ }^{7}$ The Serum CA125 is not associated with tumor progression. ${ }^{7}$ Mutation in FOXL2 gene has been identified in $97 \%$ of adult granulosa cell tumor and 10 percentage of juvenile granulosa cell tumor. ${ }^{8}$ The differential diagnosis of granulosa cell tumor are Stromal sarcoma, Carcinoid tumor, Endometrioid carcinoma and Adenocarcinoma.

The main modality of treatment is complete surgery (hysterectomy, bilateral salphingo oophorectomy) with Staging procedure according to the International Federation of Gynaecology and Obstetrics(FIGO) ovarian cancer Staging system. ${ }^{9}$ For women who wish to preserve fertility with stage 1 disease, unilateral salphingooopherectomy with uterine preservation can be done. Complete surgery should be considered after child bearing period is over (NCCN category $2 \mathrm{~B}) .{ }^{10}$ The pelvic and para aortic lymphadenectomy can be omitted as part of surgical Staging, as lymph node metastasis is rare in granulosa cell tumour. Since the majority of granulosa cell tumours are confined to one ovary at diagnosis, surgery followed by observation is an acceptable treatment. Less favourable outcomes are noted in patients with high risk, stage 1 tumours (stage IC $>10$ to $15 \mathrm{~cm}$, tumour rupture and poorly differentiated tumour) and advanced stage tumours (stage II -IV). Because of rarity of this malignant tumour, it is difficult to conduct randomized studies to define the value of adjuvant therapy in this high risk population. ${ }^{11}$

According to NCCN, the recommended options for stage II-IV tumours include platinum based chemotherapy Bleomycin, Etoposide, Cisplatin (BEP), Paclitaxel Plus Carboplatin or radiotherapy for limited disease (all are category 2B). ${ }^{10}$ Alternative chemotherapy options include Etoposide plus Cisplatin (EP), Cyclophosphamide, Doxorubicin and Cisplatin (CAP) and platinum alone. ${ }^{11}$ In children with advanced stage Juvenile granulosa cell tumors, the adjuvant chemotherapy contributes complete response which is long lasting and is usually recommended for stage $\mathrm{I} C$ disease with a high mitotic index (>20 per 10 highpower fields). ${ }^{11}$

Long surveillance is recommended as granulosa cell tumour can recur many years later. The median time to relapse is approximately 4 to 6 years after diagnosis and relapses occur even after 30 years. ${ }^{12}$ In present study, we documented recurrence 75 months after the primary surgery. The common sites of recurrence are pelvis, retroperitoneum and upper abdomen. Localised relapse can be managed with complete resection. The acceptable therapies for unresectable or sub optimally resectable tumours include cytotoxic therapy with Docetaxel, Paclitaxel, Paclitaxel with Ifosfamide, Paclitaxel with Carboplatin and VAC. ${ }^{13}$ Hormonal treatment of recurrent disease with Tamoxifen alone or Megestrol or in combination of these agents occasionally produce long term clinical response. Investigational agents in relapse setting include antiangiogenic therapy (Bevacizumab), LHRH agonists (Leuprolide) and mTOR inhibitors. ${ }^{14}$

The Overall survival is good with approximately $90 \%$ at 5 years for early stage disease. The most important prognostic variable is Stage. Malmstrom etal reported the 5 year survival rate for stage I, II and III as 94\%, 88\% and $44 \% .{ }^{15}$ The recurrence rate is also related to the stage. Ahyan's study revealed the recurrence rates of $5.4 \%, 21 \%$ and $40 \%$ for stage I, II and III respectively. We also noted the better survival rate with early stage disease, but it is not statistically significant. Ahyan's trial demonstrated that the patients with age below 60 years had better survival rate (154.6 versus 89.2 months, $\mathrm{P}=0.015){ }^{16}$

Large tumour size especially greater than $10 \mathrm{~cm}$ is associated with poor prognosis. In Sehouli's trial, survival was lower for patients with postoperative residual disease. ${ }^{17}$ Sehumer's trial demonstrated that tumour rupture was also a prognostic factor. These variables were analysed in our study but the association was not statistically significant, probably because of short scale study.

\section{CONCLUSION}

Granulosa cell tumours of ovary are rare gynaecological tumours,commonly diagnosed in early stage. The role of chemotherapy is limited, mainly used in locally advanced disease, inoperable and metastatic disease. Patients who had tumour size of more than $9.7 \mathrm{~cm}$ had more recurrence events. Patients with juvenile granulose cell tumour has poor prognosis comparing to adult subtype. Due to the rarity of this disease, several prospective studies are required to establish a consensus. 
Funding: No funding sources

Conflict of interest: None declared

Ethical approval: Not required

\section{REFERENCES}

1. Seagle BL, Ann P, Butler S, Shahabi S. Ovarian granulosa cell tumor: A National Cancer Database study. Gynecol Oncol. 2017 Aug;146(2):285-291.

2. Calaminus G, Wessalowski R, Harms GD, Öbel U. Juvenile granulosa cell tumors of the ovary in children and adolescents: results from 33 patients registered in a prospective cooperative study; Gynecol Oncol. 1997;65:447-452.

3. Segal R, DePetrillo AD, Thomas G. Clinical review of adult granulosa cell tumors of the ovary. Gynecol Oncol. 1995;56:338-344.

4. Khosla D, Dimri K, Pandey AK, Mahajan R, Trehan R. Ovarian granulosa cell tumor: Clinical features, treatment, outcome, and prognostic factors. N Am J Med Sci. 2014 Mar;6(3):133-8.

5. Pautier P, Lhommé C, Culine S, Duvillard P, Michel $\mathrm{G}$, Bidart JM et al. Adult granulosa-cell tumor of the ovary: a rétrospective study of 45 cases. Int $\mathrm{J}$ Gynecol Cancer. 1997;7:58-65.

6. Shim SH, Lee SJ, Kim DY, Kim J, Kim SN, Kang SB et al. A long-term follow-up study of 91 cases with ovarian granulosa cell tumors. Anticancer Res. 2014 Feb 1;34(2):1001-10.

7. Sekkate S, Kairouani M, Serji B, Tazi A, Mrabti H, Boutayeb S, Errihani H. Ovarian granulosa cell tumors: a retrospective study of 27 cases and a review of the literature. World J Surg Oncol. 2013 Jun 18;11(1):142.

8. D'angelo E, Mozos A, Nakayama D, Espinosa I, Catasus L, Munoz J et al. Prognostic significance of FOXL2 mutation and mRNA expression in adult and juvenile granulosa cell tumors of the ovary. Modern Pathol. 2011 Oct 1;24(10):1360.

9. Gershenson DM. Sex cord-stromal tumors of the ovary: Granulosa-stromal cell tumors. UpToDate. Avaialble at https://www.uptodate.com/contents/sexcord-stromal-tumors-of-the-ovary-granulosa- celltumors?source $=$ search_resultandsearch $=$ granulos a\%20cell\%20tumorandselectedTitle $=1 \sim 150$

10. NCCN Guidelines for Patients ${ }^{\circledR}$ | Ovarian Cancer. Available at www.nccn.org/patients/guidelines/ovarian/index.htm 1

11. van Meurs HS, Buist MR, Westermann AM, Sonke GS, Kenter GG, van der Velden J. Effectiveness of chemotherapy in measurable granulosa cell tumors: a retrospective study and review of literature. Intl J Gynecol Cancer. 2014 Mar 1;24(3):496-505.

12. G Mangili, J Ottolina, A Gadducci. Long-term follow-up is crucial after treatment for granulosa cell tumours of the ovary. Br J Cancer. 2013;109:29-34.

13. Koutroumpa I, Thomakos N, Sotiropoulou M, Trachana SP, Haidopoulos D, Zagouri F et al. Clinicopathological prognostic factors for recurrence in adult granulosa cell tumor of the ovary. Gynecol Oncol. 2014 Jun 1;133:84.

14. Kottarathil VD, Antony MA, Nair IR, Pavithran K. Recent advances in granulosa cell tumor ovary: a review. Indian J Surg Oncol. 2013 Mar 1;4(1):37-47.

15. Malmstrom H, Hogberg T, Risberg B, Simonsen E. Granulosa cell tumors of the ovary: prognostic factors and outcome. Gynecol Oncol. 1994;52:50-55.

16. Ayhan A, Salman MC, Velipasaoglu M, Sakinci M, Yuce K. Prognostic factors in adult granulosa cell tumors of the ovary: a retrospective analysis of 80 cases. J Gynecol Oncol. 2009;20:158-163.

17. Sehouli J, Drescher FS, Mustea A, Elling D, Friedmann W, Kühn W et al. Granulosa cell tumor of the ovary: 10 years follow-up data of 65 patients. Anticancer Res. 2004;24:1223-9.

Cite this article as: Deenadayalan T, Narasimhan SL, Kalaichelvi K, Ramkumar B, Padmanabhan KM. Single tertiary care centre experience of ovarian granulosa cell tumour in Chennai, India: a retrospective analysis. Int $\mathrm{J}$ Reprod Contracept Obstet Gynecol 2017;6:5122-8. 